\title{
Effects of Sulfur Fertilization on Antioxidant Capacity of Wumeng Semi-Fine Wool Sheep in the Wumeng Prairie
}

\author{
Yuanfeng Li ${ }^{1}$, Yachao Wang ${ }^{1 \#}$, Xiaoyun Shen ${ }^{1,2,3 *}$ \\ ${ }^{1}$ School of Life Science and Engineering, Southwest University of Science and Technology, Mianyang 621000, China \\ ${ }^{2}$ State Engineering Technology Institute for Karst Desertification Control, Guizhou Normal University, \\ Guiyang 550025, China \\ ${ }^{3}$ World Bank Poverty Alleviation Project Office in Guizhou, Southwest China, Guiyang 550004, China
}

Received: 16 November 2020

Accepted: 25 January 2021

\begin{abstract}
To assess the impact of sulfur(S) fertilization on antioxidant capacity of grazing Wumeng semifine wool sheep in copper $(\mathrm{Cu})$ polluted meadow, and explore the control methods of $\mathrm{Cu}$ pollution in natural pasture, fertilizer treatment and grazing experiments were carried out in Weining County of the Wumeng Prairie, Guizhou Province, Southwest China. 24 ha Cu-polluted meadows were fenced, and randomly divided into four groups (3 replications/group, 2 ha/replication): 1) control group, no fertilizer; 2) the tested groups, applied ammonium sulfate $\left[(\mathrm{NH} 4)_{2} \mathrm{SO}_{4}\right](300,400$, and $500 \mathrm{~kg} / \mathrm{ha}$ for group I, group II, and group III, respectively). A total of 72 healthy Wumeng semi-fine wool sheep (aged one year, $32.8 \pm 1.3 \mathrm{~kg}$ ) were used in this study. All animals were randomly divided into 4 groups (3 replications/group, 6 sheep/replication) and assigned to the tested pastures. The grazing experiment lasted for 60 days. The results showed that the contents of $\mathrm{N}, \mathrm{Mn}, \mathrm{Zn}$, and $\mathrm{S}$ in herbage in fertilized pastures were markedly higher than those in control group $(\mathrm{P}<0.01)$. The contents of $\mathrm{Cu}, \mathrm{Fe}$, and $\mathrm{Se}$ in herbage in fertilized pastures were significantly lower than those in control group $(\mathrm{P}<0.01)$. There were no extreme differences among the fertilized pastures $(\mathrm{P}>0.05)$. The contents of $\mathrm{Mn}, \mathrm{Zn}$, and $\mathrm{S}$ in serum and liver in the tested sheep were significantly higher than those in control animals $(\mathrm{P}<0.01)$. The contents of $\mathrm{Cu}, \mathrm{Fe}$, and $\mathrm{Se}$ in serum and liver in the tested sheep were extremely lower than those in control animals $(\mathrm{P}<0.01)$. The levels of $\mathrm{Hb}, \mathrm{RBC}$, and $\mathrm{PCV}$ in blood in the tested sheep, and the activities of serum SOD, GSH-Px, T-AOC, CAT, and $\mathrm{Cp}$ in the tested sheep were extremely higher than those in control sheep $(\mathrm{P}<0.01)$. The contents of serum MDA in the tested sheep were significantly lower than those in control animals $(\mathrm{P}<0.01)$. There were no great differences among the tested groups in physiological and biochemical parameters $(\mathrm{P}>0.05)$. The current results indicated that fertilization of
\end{abstract}


(NH4)2SO4 not only markedly influenced the mineral contents of herbage, and samples of blood and liver, but also extremely improved antioxidant capacity in grazing animals from fertilized pastures.

Keywords: Wumeng semi-fine wool sheep, copper polluted meadow, fertilization treatment, mineral content, antioxidant capacity

\section{Introduction}

The Wumeng Prairie is located in the northwest of Guizhou Province, Southwest China. It has extremely rich mineral resources. Over the last 10 years, due to rapid development of metallurgical industries, as a result, a large number of heavy metals had been produced in the Wumeng Prairie [1]. The $\mathrm{Cu}$ contents in water, soil, and forage have increased extremely in Weining County of the Wumeng Prairie, Guizhou Province, Southwest China. $\mathrm{Cu}$ elements are not easy to decompose in natural pasture, so the polluted natural ranges are very difficult to be repaired [1]. Cu pollution not only seriously damaged animal husbandry, but also greatly threatened human health through the food chain $[2,3]$.

The Wumeng Prairie is a key pastureland for Wumeng semi-fine wool sheep. These native sheep were also vital to the production system in the Wumeng Prairie, and mainly distributed in the high altitude pasture in Weining County of the Wumeng Prairie, Southwest China $[4,5]$. Wumeng semi-fine wool sheep have high growth performance, mild temperament and strong adaptability to alpine pastoral ranges $[6,7]$. However, their natural habitats in the Wumeng Prairie have been seriously polluted by heavy metals. Heavy metal pollution leads to the destruction of soil structure and loss of soil fertility, which not only affects the yield and quality of forages but also badly damages animal and human health [8]. The sheep industry is also grievously hindered in the Wumeng Prairie, Southwest China. Therefore, it is urgent to explore the effective control measures of $\mathrm{Cu}$ pollution in the Wumeng Prairie. To reduce the intake of heavy metals in human beings, the most effective way is to keep heavy metals out of plants and animals. The previous study found that sulfur in feed is converted into sulfide in the rumen, leading to precipitation of $\mathrm{Cu}$ sulfide and hindering the absorption and utilization of $\mathrm{Cu}$ [8]. The interference means of fertilization and grazing might change the biodiversity of grazing land and foraging strategies in grazing animal, as a result, pollution elements into the animal body is reduced [9]. Adjusting the soil $\mathrm{pH}$ and increasing contents of organic matter can much change the activities of heavy metals in soil, and the bioavailability of heavy metals is also reduced. However, it will take a long time to control heavy metal pollution.

The objective of this study was to determine the effects of $\mathrm{S}$ fertilization and grazing measures on antioxidant capacity of Wumeng semi-fine wool sheep, and explore the new methods and technologies for the management of $\mathrm{Cu}$-polluted pastures.

\section{Materials and Methods}

\section{Purchase of Ammonium Sulfate}

Ammonium sulfate $\left[\left(\mathrm{NH}_{4}\right)_{2} \mathrm{SO}_{4}\right]$ was purchased from Luxi Chemical Industry Group Co. Ltd., with purity of no less than $99 \%$.

\section{Experimental Design}

The Cu-polluted pastures were located in Weining County of the Wumeng Prairie, Guizhou Province. Before the test, the mineral contents in soil, herbage, samples of serum and liver were analyzed. 24 ha $\mathrm{Cu}$-polluted meadow was selected for this study, and randomly divided into four groups (3 replications/ group, 2 ha/replication): 1) control group, with no fertilizer; 2) the tested groups, applied $\left(\mathrm{NH}_{4}\right)_{2} \mathrm{SO}_{4}(300$, 400 , and $500 \mathrm{~kg} /$ ha for group I, group II, and group III, respectively). 72 healthy Wumeng semi-fine wool sheep (aged one year, $32.8 \pm 1.3 \mathrm{~kg}$ ) were used in this study. All animals were randomly divided into four groups (3 replications/group, 6 sheep/replication) and assigned to the fertilized pastures. The grazing experiment lasted for 60 days.

\section{Feeding Management}

The experimental houses were all semi-open type, and thoroughly cleaned and disinfected during the trial period. The houses were disinfected twice/a month ( $2 \%$ caustic soda or $0.5 \%$ povidone iodine, alternate use). Animals were grazing in the daytime and fed concentrate supplementation at 18:00 once a day. Water provided ad libitum. The health status of sheep was recorded every day.

\section{Sample Collection and Analysis}

Soil and herbage samples were collected and prepared according to Huo et al. [10]. On day 60 of the experiment, after fasting for 12 hours, blood samples were collected from the jugular vein into vacuum blood collection tubes with EDTA- $\mathrm{K}_{2}$ anticoagulant, and stored at $4^{\circ} \mathrm{C}$ for up 4 hours until assay of hematology examination. Serum samples were collected using vacuum blood collection tubes with $1 \%$ heparin sodium, separated by centrifuge at $3000 \times \mathrm{g}$ for $15 \mathrm{~min}$, 
Table 1. The mineral contents in soil and herbage in $\mathrm{Cu}$-polluted pasture.

\begin{tabular}{|c|c|c|}
\hline Items & Soil & Herbage \\
\hline $\mathrm{Mn}(\mathrm{mg} / \mathrm{kg})$ & $202.24 \pm 27.17$ & $61.54 \pm 10.20$ \\
\hline $\mathrm{Zn}(\mathrm{mg} / \mathrm{kg})$ & $52.12 \pm 11.08$ & $84.62 \pm 12.21$ \\
\hline $\mathrm{Co}(\mathrm{mg} / \mathrm{kg})$ & $6.48 \pm 1.28$ & $1.48 \pm 0.35$ \\
\hline $\mathrm{Cu}(\mathrm{mg} / \mathrm{kg})$ & $76.87 \pm 4.93 \mathrm{a}$ & $37.22 \pm 2.61 \mathrm{a}$ \\
\hline $\mathrm{Fe}(\mathrm{mg} / \mathrm{kg})$ & $15008.42 \pm 275.15$ & $318.63 \pm 20.51$ \\
\hline $\mathrm{Mo}(\mathrm{mg} / \mathrm{kg})$ & $1.88 \pm 0.35$ & $1.22 \pm 0.15$ \\
\hline $\mathrm{Se}(\mathrm{mg} / \mathrm{kg})$ & $0.12 \pm 0.02$ & $0.12 \pm 0.01$ \\
\hline $\mathrm{S}(\%)$ & $0.18 \pm 0.04$ & $0.25 \pm 0.02$ \\
\hline
\end{tabular}

Note: $\mathrm{Mn}=$ manganese, $\mathrm{Zn}=$ zinc, $\mathrm{Co}=$ cobalt, $\mathrm{Cu}=$ copper, $\mathrm{Fe}=$ iron, $\mathrm{Mo}=$ molybdenum, $\mathrm{Se}=$ selenium, $\mathrm{S}=$ sulphur. Different lowercase letters in the same trade indicates significant difference at $P<0.01$ level.

and stored in an EP tube at $-80^{\circ} \mathrm{C}$ for analysis of trace elements and enzyme activities. The living liver samples of Wumeng semi-fine wool sheep were collected by skilled technicians through liver puncture, fixed in the sample bottle, then stored at $-80^{\circ} \mathrm{C}$ until analyzed.

Soil samples were naturally dried at $20-25^{\circ} \mathrm{C}$ and crushed, then passed through a $0.075-\mathrm{mm}$ sieve used to remove silver sand. Herbage and blood samples were heated and digested by microwave radiation in sealed pot, then determined by computer. The levels of manganese $(\mathrm{Mn})$, zinc $(\mathrm{Zn})$, cobalt $(\mathrm{Co})$, copper $(\mathrm{Cu})$, iron (Fe), molybdenum (Mo), and selenium (Se) were performed by Perkin Elmer, Norwalk, USA. Nitrogen (N) element was analyzed by silver nitrate titration [11], and $\mathrm{S}$ element was analyzed by barium sulfate gravimetric method [12].

Levels of hemoglobin ( $\mathrm{Hb})$, erythrocyte count (RBC), packed cell volume (PCV), and white blood cell count (WBC) were determined by automatic blood cell analyzer (SF-3000, Sysmex-Toa Medical Electronics, Kobe, Japan). Serum superoxide dismutase (SOD), glutathione peroxidase (GSH-Px), total antioxidant capacity (T-AOC), catalase (CAT), malondialdehyde (MDA), and ceruloplasmin(Cp) were determined using commercial test kits (Nanjing Jiancheng BioEngineering Institute, China).

\section{Statistical Analyses}

Experimental data were analyzed by using the statistical package (SPSS, version 23.0, Inc., Chicago, Illinois, USA), and presented in the form of mean \pm standard deviation (SD). One way ANOVA program was used to analyze the data and Duncan method was used for multiple comparisons. A probability level of $P<0.01$ were considered to be extremely significant. $P>0.05$ indicates no significant difference.

\section{Results}

\section{The Mineral Contents in Soil and Herbage}

As shown in Table 1, the contents of $\mathrm{Cu}$ in soil and forage were 76.87 and $37.22 \mathrm{mg} / \mathrm{kg}$, respectively, far exceeding the normal levels [13].

\section{Effects of S Fertilization on Mineral Contents in Herbage}

As shown in Table 2, compared to control group, the contents of $\mathrm{N}, \mathrm{Mn}, \mathrm{Zn}$, and $\mathrm{S}$ in the tested groups extremely increased $(P<0.01)$, and the contents of $\mathrm{Cu}$, $\mathrm{Fe}$, and $\mathrm{Se}$ in the tested groups significantly decreased $(P<0.01)$, but there were no extreme differences among the tested groups $(P>0.05)$.

Table 2. Effects of S fertilization on mineral contents in herbage in $\mathrm{Cu}$-polluted pasture.

\begin{tabular}{|c|c|c|c|c|}
\hline Items & Control & Group I & Group II & Group III \\
\hline $\mathrm{N}(\%)$ & $2.29 \pm 0.20 \mathrm{~b}$ & $3.52 \pm 0.22 \mathrm{a}$ & $3.58 \pm 0.21 \mathrm{a}$ & $3.62 \pm 0.23 \mathrm{a}$ \\
\hline $\mathrm{Mn}(\mathrm{mg} / \mathrm{kg})$ & $61.52 \pm 10.21 \mathrm{~b}$ & $81.72 \pm 14.90 \mathrm{a}$ & $85.33 \pm 10.61 \mathrm{a}$ & $86.82 \pm 16.60 \mathrm{a}$ \\
\hline $\mathrm{Zn}(\mathrm{mg} / \mathrm{kg})$ & $84.64 \pm 12.20 \mathrm{~b}$ & $104.64 \pm 12.10 \mathrm{a}$ & $114.62 \pm 10.93 \mathrm{a}$ & $115.83 \pm 16.21 \mathrm{a}$ \\
\hline $\mathrm{Co}(\mathrm{mg} / \mathrm{kg})$ & $1.48 \pm 0.35$ & $1.37 \pm 0.12$ & $1.43 \pm 0.11$ & $1.52 \pm 0.18$ \\
\hline $\mathrm{Cu}(\mathrm{mg} / \mathrm{kg})$ & $17.26 \pm 2.63 \mathrm{a}$ & $12.92 \pm 2.10 \mathrm{~b}$ & $13.02 \pm 2.20 \mathrm{~b}$ & $13.74 \pm 2.01 \mathrm{~b}$ \\
\hline $\mathrm{Fe}(\mathrm{mg} / \mathrm{kg})$ & $318.64 \pm 20.51 \mathrm{a}$ & $285.43 \pm 11.31 \mathrm{~b}$ & $289.24 \pm 10.11 \mathrm{~b}$ & $290.52 \pm 20.30 \mathrm{~b}$ \\
\hline $\mathrm{Mo}(\mathrm{mg} / \mathrm{kg})$ & $1.22 \pm 0.15$ & $1.21 \pm 0.10$ & $1.29 \pm 0.13$ & $1.24 \pm 0.12$ \\
\hline $\mathrm{Se}(\mathrm{mg} / \mathrm{kg})$ & $0.12 \pm 0.01 \mathrm{a}$ & $0.07 \pm 0.02 \mathrm{~b}$ & $0.08 \pm 0.01 \mathrm{~b}$ & $0.08 \pm 0.02 \mathrm{~b}$ \\
\hline $\mathrm{S}(\%)$ & $0.25 \pm 0.02 \mathrm{~b}$ & $0.32 \pm 0.05 \mathrm{a}$ & $0.31 \pm 0.07 \mathrm{a}$ & $0.33 \pm 0.03 \mathrm{a}$ \\
\hline
\end{tabular}

Note: $\mathrm{N}=$ nitrogen, $\mathrm{Mn}=$ manganese, $\mathrm{Zn}=$ zinc, $\mathrm{Co}=$ cobalt, $\mathrm{Cu}=$ copper, $\mathrm{Fe}=$ iron, $\mathrm{Mo}=$ molybdenum, $\mathrm{Se}=$ selenium, $\mathrm{S}=$ sulphur. Different lowercase letters in the same trade indicates significant difference at $P<0.01$ level. 


\section{Effects of S Fertilization on Mineral Contents in Serum}

As shown in Table 3, compared to control group, the contents of serum $\mathrm{Mn}, \mathrm{Zn}$, and $\mathrm{S}$ in the tested groups extremely increased $(P<0.01)$, and the contents of serum $\mathrm{Cu}, \mathrm{Fe}$, and $\mathrm{Se}$ significantly decreased $(P<0.01)$, but there were no extreme difference among the tested groups $(P>0.05)$.

\section{Effects of S Fertilization on Mineral Elements in Liver}

As shown in Table 4, compared to control group, the contents of liver $\mathrm{Mn}, \mathrm{Zn}$, and $\mathrm{S}$ in the tested groups extremely increased $(P<0.01)$, and the contents of liver $\mathrm{Cu}, \mathrm{Fe}$, and $\mathrm{Se}$ significantly decreased $(P<0.01)$, but there were no extreme difference among the tested groups $(P>0.05)$.

Table 3. Effects of S fertilization on mineral contents in serum of grazing sheep.

\begin{tabular}{|c|c|c|c|c|}
\hline Items & Control & Group I & Group II & Group III \\
\hline $\mathrm{Mn}(\mathrm{mg} / \mathrm{kg})$ & $0.52 \pm 0.04 \mathrm{~b}$ & $0.77 \pm 0.11 \mathrm{a}$ & $0.75 \pm 0.10 \mathrm{a}$ & $0.73 \pm 0.12 \mathrm{a}$ \\
\hline $\mathrm{Zn}(\mathrm{mg} / \mathrm{kg})$ & $7.40 \pm 0.13 \mathrm{~b}$ & $8.65 \pm 0.12 \mathrm{a}$ & $8.68 \pm 0.10 \mathrm{a}$ & $8.67 \pm 0.10 \mathrm{a}$ \\
\hline $\mathrm{Co}(\mathrm{mg} / \mathrm{kg})$ & $0.67 \pm 0.12$ & $0.66 \pm 0.18$ & $0.71 \pm 0.20$ & $0.70 \pm 0.15$ \\
\hline $\mathrm{Cu}(\mathrm{mg} / \mathrm{kg})$ & $6.56 \pm 0.55 \mathrm{a}$ & $3.38 \pm 0.55 \mathrm{~b}$ & $3.49 \pm 0.42 \mathrm{~b}$ & $3.46 \pm 0.33 \mathrm{~b}$ \\
\hline $\mathrm{Fe}(\mathrm{mg} / \mathrm{kg})$ & $374.91 \pm 38.22 \mathrm{a}$ & $314.84 \pm 40.21 \mathrm{~b}$ & $310.83 \pm 55.20 \mathrm{~b}$ & $315.74 \pm 38.21 \mathrm{~b}$ \\
\hline $\mathrm{Mo}(\mathrm{mg} / \mathrm{kg})$ & $0.07 \pm 0.02$ & $0.08 \pm 0.01$ & $0.09 \pm 0.03$ & $0.07 \pm 0.02$ \\
\hline $\mathrm{Se}(\mathrm{mg} / \mathrm{kg})$ & $0.16 \pm 0.03 \mathrm{a}$ & $0.10 \pm 0.03 \mathrm{~b}$ & $0.10 \pm 0.02 \mathrm{~b}$ & $0.13 \pm 0.02 \mathrm{~b}$ \\
\hline $\mathrm{S}(\%)$ & $0.08 \pm 0.02 \mathrm{~b}$ & $0.12 \pm 0.03 \mathrm{a}$ & $0.13 \pm 0.02 \mathrm{a}$ & $0.13 \pm 0.02 \mathrm{a}$ \\
\hline
\end{tabular}

Note: $\mathrm{Mn}=$ manganese, $\mathrm{Zn}=$ zinc, $\mathrm{Co}=$ cobalt, $\mathrm{Cu}=$ copper, $\mathrm{Fe}=$ iron, $\mathrm{Mo}=$ molybdenum, $\mathrm{Se}=$ selenium, $\mathrm{S}=$ sulphur. Different lowercase letters in the same trade indicates significant difference at $P<0.01$ level.

Table 4. Effects of S fertilization on mineral contents in liver of grazing sheep.

\begin{tabular}{|c|c|c|c|c|}
\hline Items & Control & Group I & Group II & Group III \\
\hline $\mathrm{Mn}(\mathrm{mg} / \mathrm{kg})$ & $4.11 \pm 1.36 \mathrm{~b}$ & $5.15 \pm 1.20 \mathrm{a}$ & $5.21 \pm 1.35 \mathrm{a}$ & $5.28 \pm 1.33 \mathrm{a}$ \\
\hline $\mathrm{Zn}(\mathrm{mg} / \mathrm{kg})$ & $76.45 \pm 11.82 \mathrm{~b}$ & $83.63 \pm 16.21 \mathrm{a}$ & $87.42 \pm 18.50 \mathrm{a}$ & $81.84 \pm 15.70 \mathrm{a}$ \\
\hline $\mathrm{Co}(\mathrm{mg} / \mathrm{kg})$ & $7.31 \pm 1.09$ & $7.34 \pm 1.21$ & $7.31 \pm 1.30$ & $7.46 \pm 1.08$ \\
\hline $\mathrm{Cu}(\mathrm{mg} / \mathrm{kg})$ & $1868.26 \pm 40.11 \mathrm{a}$ & $1078.42 \pm 26.15 \mathrm{~b}$ & $1001.21 \pm 28.15 \mathrm{~b}$ & $1039.22 \pm 28.10 \mathrm{~b}$ \\
\hline $\mathrm{Fe}(\mathrm{mg} / \mathrm{kg})$ & $351.08 \pm 37.12 \mathrm{a}$ & $305.12 \pm 18.04 \mathrm{~b}$ & $308.07 \pm 13.05 \mathrm{~b}$ & $304.34 \pm 19.06 \mathrm{~b}$ \\
\hline $\mathrm{Mo}(\mathrm{mg} / \mathrm{kg})$ & $2.98 \pm 0.30$ & $2.82 \pm 0.23$ & $2.79 \pm 0.22$ & $2.81 \pm 0.23$ \\
\hline $\mathrm{Se}(\mathrm{mg} / \mathrm{kg})$ & $1.23 \pm 0.06 \mathrm{a}$ & $0.86 \pm 0.04 \mathrm{~b}$ & $0.88 \pm 0.03 \mathrm{~b}$ & $0.90 \pm 0.02 \mathrm{~b}$ \\
\hline $\mathrm{S}(\%)$ & $0.68 \pm 0.02 \mathrm{~b}$ & $1.21 \pm 0.03 \mathrm{a}$ & $1.28 \pm 0.02 \mathrm{a}$ & $1.30 \pm 0.02 \mathrm{a}$ \\
\hline
\end{tabular}

Note: $\mathrm{Mn}=$ manganese, $\mathrm{Zn}=$ zinc, $\mathrm{Co}=$ cobalt, $\mathrm{Cu}=$ copper, $\mathrm{Fe}=$ iron, $\mathrm{Mo}=$ molybdenum, $\mathrm{Se}=$ selenium, $\mathrm{S}=$ sulphur.

Different lowercase letters in the same trade indicates significant difference at $P<0.01$ level.

Table 5. Effects of S fertilization on physiological indexes of grazing sheep in Cu-polluted pasture.

\begin{tabular}{|c|c|c|c|c|}
\hline Items & Control & Group I & Group II & Group III \\
\hline $\mathrm{Hb}\left(\mathrm{g} \mathrm{L}^{-1}\right)$ & $83.12 \pm 12.50 \mathrm{~b}$ & $103.00 \pm 11.62 \mathrm{a}$ & $103.24 \pm 11.90 \mathrm{a}$ & $102.32 \pm 13.81 \mathrm{a}$ \\
\hline $\mathrm{RBC}\left(10^{12} \mathrm{~L}^{-1}\right)$ & $6.83 \pm 1.11 \mathrm{~b}$ & $9.53 \pm 1.81 \mathrm{a}$ & $9.83 \pm 1.52 \mathrm{a}$ & $9.72 \pm 1.30 \mathrm{a}$ \\
\hline $\mathrm{PCV}(\%)$ & $30.52 \pm 2.30 \mathrm{~b}$ & $32.42 \pm 2.13 \mathrm{a}$ & $32.51 \pm 1.73 \mathrm{a}$ & $32.03 \pm 2.50 \mathrm{a}$ \\
\hline $\mathrm{WBC}\left(10^{9} \mathrm{~L}^{-1}\right)$ & $10.52 \pm 1.50$ & $9.61 \pm 1.32$ & $9.94 \pm 1.20$ & $10.43 \pm 1.31$ \\
\hline
\end{tabular}

Note: $\mathrm{Hb}=$ hemoglobin, $\mathrm{RBC}=$ erythrocyte count, $\mathrm{PCV}=$ packcd cell volume, $\mathrm{WBC}=$ white blood cell count.

Different lowercase letters in the same trade indicates significant difference at $P<0.01$ level. 
Table 6. Effects of S fertilization on antioxidant capacity of grazing sheep in Cu-polluted pasture.

\begin{tabular}{|c|c|c|c|c|}
\hline Items & Control & Group I & Group II & Group III \\
\hline SOD $(\mathrm{IU} / \mathrm{mL})$ & $33.95 \pm 2.92 \mathrm{~b}$ & $58.53 \pm 4.62 \mathrm{a}$ & $55.73 \pm 3.82 \mathrm{a}$ & $57.22 \pm 4.30 \mathrm{a}$ \\
\hline GSH-Px $(\mathrm{IU} / \mathrm{mL})$ & $24.14 \pm 2.90 \mathrm{~b}$ & $29.64 \pm 2.72 \mathrm{a}$ & $29.54 \pm 4.13 \mathrm{a}$ & $29.84 \pm 3.22 \mathrm{a}$ \\
\hline T-AOC $(\mathrm{IU} / \mathrm{mL})$ & $6.85 \pm 1.66 \mathrm{~b}$ & $7.96 \pm 0.85 \mathrm{a}$ & $7.88 \pm 0.96 \mathrm{a}$ & $7.93 \pm 0.63 \mathrm{a}$ \\
\hline CAT $(\mathrm{IU} / \mathrm{mL})$ & $0.73 \pm 0.15 \mathrm{~b}$ & $1.04 \pm 0.12 \mathrm{a}$ & $1.05 \pm 0.11 \mathrm{a}$ & $1.08 \pm 0.12 \mathrm{a}$ \\
\hline MDA $(\mathrm{nmol} / \mathrm{mL})$ & $35.34 \pm 3.21 \mathrm{a}$ & $31.23 \pm 2.62 \mathrm{~b}$ & $31.03 \pm 3.10 \mathrm{~b}$ & $31.43 \pm 3.21 \mathrm{~b}$ \\
\hline Cp $(\mathrm{BU} / \mathrm{dL})$ & $8.82 \pm 1.18 \mathrm{~b}$ & $10.39 \pm 1.12 \mathrm{a}$ & $10.93 \pm 0.95 \mathrm{a}$ & $11.06 \pm 1.15 \mathrm{a}$ \\
\hline
\end{tabular}

Note: $\mathrm{SOD}=$ superoxide dismutase, GSH-Px $=$ glutathione peroxide, $\mathrm{T}-\mathrm{AOC}=$ total antioxidant capacity, $\mathrm{CAT}=$ catalase, $\mathrm{MDA}=$ malondialdehyde, $\mathrm{Cp}=$ ceruloplasmin. Different lowercase letters in the same trade indicates significant difference at $P<0.01$ level.

\section{Effects of S Fertilization on Physiological Indexes}

As shown in Table 5, compared to control group, the levels of $\mathrm{Hb}, \mathrm{RBC}$, and PCV in the tested groups extremely increased $(P<0.01)$, but there were no extreme difference among the tested groups $(P>0.05)$.

\section{Effects of S Fertilization on Antioxidant Capacity}

As shown in Table 6, compared to control group, the activities of serum SOD, GSH-Px, T-AOC, CAT, and $\mathrm{Cp}$ extremely increased in the tested groups $(P<0.01)$, and the contents of serum MDA significantly decreased $(P<0.01)$, but there were no extreme difference among the tested groups $(P>0.05)$.

\section{Discussion}

\section{Effects of S Fertilization on Mineral Elements in Herbage}

Mineral elements are key nutrients for animals and humans [5, 14]. Too high contents of mineral elements in soil and herbage will cause mineral poisoning in animals [15]. Therefore, the study on the characteristics of mineral elements in soil, herbage, and livestock can not only clarify the distribution law of minerals in pasture, but also help to understand status of nutrition in grazing animals $[16,17]$.

$\mathrm{N}$ and $\mathrm{S}$ are important nutrients in plants. The previous study found that application of $\left(\mathrm{NH}_{4}\right)_{2} \mathrm{SO}_{4}$ can extremely increase the contents of $\mathrm{N}$ and $\mathrm{S}$ in herbage [18]. The $\mathrm{Cu}$ content of forage from the tested pasture in this study was $76.87 \mathrm{mg} / \mathrm{kg}$, higher than the soil environmental quality risk control standard of soil contamination of agricultural land in China [13]. The ion concentrations in soil were serious influenced by $\left(\mathrm{NH}_{4}\right)_{2} \mathrm{SO}_{4}$ treatment. The physical and chemical properties of soil had changed greatly. The status of the mineral nutrition in soil was also altered, as a result, the diversity of plant community and the mineral contents in herbage was greatly affected in pasture [19]. In this study, the contents of N, Zn, Mn, and S in fertilized pastures extremely increased and the contents of $\mathrm{Cu}, \mathrm{Fe}$, and $\mathrm{Se}$ greatly reduced. These results were different from the study of Shen XY et al. [18]. This might be related to the mineral contents in soil before the experiments.

Generally, $\left(\mathrm{NH}_{4}\right)_{2} \mathrm{SO}_{4}$ is dissolved in water solution in soil and ionized into ammonium ion and sulfate ion. Because the amount of ammonium ions selectively absorbed by plants is larger than those of sulfate ions, the residual sulfate ions in soil combine with hydrogen ions and make soil acid [20], which is associated with an increase in $\mathrm{Zn}$ and $\mathrm{Mn}$ uptake in forage [12]. Therefore, in this study, the contents of $\mathrm{Zn}$ and $\mathrm{Mn}$ in forage in fertilized pastures significantly increased.

$\mathrm{S}$ element is an important factor affecting the absorption of Se by plants. The solubility of selenate in soil is higher than that of selenite, often coexists with sulfate and is easy to be absorbed by plants [14]. It was found that there was a competitive antagonism between selenate and sulfate. Selenate and sulfate competed for the same absorption site in plant roots, and the ratio of selenate and sulfate determined their absorption degree [21]. Therefore, the interaction between $\mathrm{S}$ and Se was the main reason for the low Se contents in herbage in $\left(\mathrm{NH}_{4}\right)_{2} \mathrm{SO}_{4}$ fertilized pastures [21]. $\mathrm{S}$ fertilization accelerated the transfer of Se from soil to plants. The available Se contents in soil inevitably decreased with the growth of plants, then the Se contents in plants reduced. However, the interaction between $\mathrm{S}$ and $\mathrm{Se}$ was very complex and needed further study.

\section{Effects of S Fertilization on Antioxidant Capacity}

There are harmful consequences of extremely excessive mineral nutrients in animals and humans. The number of reported chronic $\mathrm{Cu}$ poisoning cases rises steadily in China, due partly to the growing popularity of susceptible breeds, such as Wumeng semi-fine wool 
sheep $[8,22,23]$. In addition, metallothionein (MT) and metal binding protein (MBP) can be regulated to prevent or reduce its toxicity. $\mathrm{Cu}$ plays an important role in enhancing immune function $[24,25]$. A large number of oxygen free radicals are produced in the metabolism of the body, which causes denaturation of protein and nucleic acid, degradation of polysaccharide and formation of lipid peroxide [26]. Oxygen free radicals produce hydrogen peroxide under the action of SOD. Hydrogen peroxide is degraded and removed by CAT and GSH-Px, which keeps the organism in a good immune state [27]. $\mathrm{Cu}$ is also a component of SOD catalytic center in organism, which is related to SOD catalytic activity [22]. When the $\mathrm{Cu}$ content in the body is extremely excessive, it shows certain toxicity. Excessive $\mathrm{Cu}$ promotes the oxidative modification of low-density lipoprotein (LDL). The lipid peroxidation produced malondialdehyde and other lipid peroxides, as a result, organism is damaged by the free radicals [28].

The liver is the key organ for storing $\mathrm{Cu}$ in animals. High $\mathrm{Cu}$ can damage the subcellular structures, such as the nucleus, mitochondria, and serous fluid of liver [29]. If the $\mathrm{Cu}$ intake in liver exceeds its tolerance limit, it can inhibit the activities of various enzymes, and causes necrosis of liver cells. This makes the dysfunction of liver excreting $\mathrm{Cu}$, then leads to $\mathrm{Cu}$ accumulation. When the $\mathrm{Cu}$ concentration in liver is very high, a large amount of $\mathrm{Cu}$ is released into blood, then enters into red blood cells in the action of certain inducement. The continuously increasing of intracellular $\mathrm{Cu}$ will greatly reduce the concentration of glutathione in red blood cells, increase the brittleness of red blood cells, and cause intravascular hemolysis [30,31], as a result, hemolytic anemia occurs [31]. The previous study found that $\mathrm{S}$ interference with $\mathrm{Cu}$ absorption caused $\mathrm{Cu}$ deficiency in Wumeng semi-fine wool sheep [31]. In normal conditions, most of $\mathrm{Cu}$ in blood exists in the form of ceruloplasmin $(\mathrm{Cp})$. $\mathrm{Cp}$ has the function of ferrous oxidase and anti-oxidation. The lack of $\mathrm{Cu}$ often leads to the decrease of $\mathrm{Cp}$ in blood. Generally, $\mathrm{Fe}^{3+}$ in food is reduced to $\mathrm{Fe}^{2+}$ in gastrointestinal tract before it can be absorbed by animals. $\mathrm{Fe}^{2+}$ enters animal body, combines with carboxyferritin and is changed into $\mathrm{Fe}^{3+}$, then stored in liver. $\mathrm{Fe}^{3+}$ in liver can be reduced to $\mathrm{Fe}^{2+}$ again and enters into blood. $\mathrm{Fe}^{2+}$ in blood is oxidized to $\mathrm{Fe}^{3+}$, then $\mathrm{Fe}^{3+}$ combines with $\beta$-globulin to form iron transfer protein, which is sent to bone marrow to synthesize $\mathrm{Hb}$. In vivo $\mathrm{Cp}$ regulates the transformation between liver $\mathrm{Fe}^{3+}$ and blood $\mathrm{Fe}^{2+}$ [31]. Therefore, the decreased $\mathrm{Cp}$ concentration in blood will cause that Fe stored in liver cannot be mobilized. Fe stored in the phagocytes cannot enter blood, as a result, Fe content in blood decreases, and hemolytic anemia occurs in animals [11, 31]. In this study, the contents of blood $\mathrm{Cu}$ and $\mathrm{Fe}$ in $\left(\mathrm{NH}_{4}\right)_{2} \mathrm{SO}_{4}$ treatment significantly reduced in grazing animals from fertilized pastures, but the $\mathrm{Cu}$ contents were still far higher than the healthy level, so the anemia symptoms of grazing sheep were only relieved to some extent.
The antioxidant system is the defense system for scavenging free radicals, comprising non-enzymatic $(\mathrm{Cu}, \mathrm{Fe}, \mathrm{Zn}, \mathrm{Se})$ and enzymatic systems (SOD, GSHPx, T-AOC, CAT, and other antioxidant enzymes) [3234]. SOD can catalyze the superoxide anion $\left(\mathrm{O}^{2-}\right)$ to produce disproportionation reaction, remove superoxide anion, and protect cells from damage [35,36]. GSH-Px and CAT can clear $\mathrm{H}_{2} \mathrm{O}_{2}$ in the body, so as to protect cells from $\mathrm{H}_{2} \mathrm{O}_{2}$ damage [28]. As the comprehensive indicator for evaluating levels of antioxidant enzymes and the non-enzymatic system in animal organisms, T-AOC can reflect the compensatory capacity to external stimuli and the metabolism capacity of free radicals [22, 37]. Decreased level of T-AOC cannot keep antioxidant system active, leading to the abundance of lipid peroxides and free radicals. MDA is a lipid peroxide, which can reflect the degree of lipid peroxidation in the body [38]. The reaction product of SOD is the substrate of GSH-Px [39]. The radical scavenging of $\mathrm{O}^{2-}$ requires continuous catalysis from SOD, GSH-Px, and CAT [40,41]. Therefore, SOD, GSH-Px, and CAT play a more important role in blocking membrane lipid peroxidation induced by free radicals. In our study, the contents of mineral elements in herbage were extremely affected by application of $\left(\mathrm{NH}_{4}\right)_{2} \mathrm{SO}_{4}$ fertilization. The $\mathrm{Cu}$ contents in herbage, serum, and liver of grazing animals were significantly higher than those in control group, the activities of serum SOD, GSH-Px, T-AOC, CAT, and $\mathrm{Cp}$ were significantly lower than those in control group. The contents of MDA were extremely higher than those in control group. Although the contents of $\mathrm{Mn}, \mathrm{Zn}$, and $\mathrm{S}$ in serum and liver extremely increased, and the activities of antioxidant enzymes in serum significantly enhanced, application of $\mathrm{S}$ fertilization could not interfere with the $\mathrm{Cu}$ metabolism of Wumeng semi-fine wool sheep. Therefore, hemolytic anemia still occurred in grazing animals in Cu-polluted meadows. Application of S fertilization only partly alleviated the $\mathrm{Cu}$ toxicity on antioxidant system in grazing Wumeng semi-fine wool sheep.

\section{Conclusion}

The $\mathrm{Cu}$ contents in herbage were significantly influenced by $\mathrm{S}$ fertilization in $\mathrm{Cu}$-polluted pastures, but it cannot completely eliminate damage of the $\mathrm{Cu}$ pollution on antioxidant capacity in grazing Wumeng semi-fine wool sheep. It is necessary to further explore the methods to control $\mathrm{Cu}$ pollution in natural range lands.

\section{Acknowledgements}

We gratefully acknowledge support by the Project of National Key Research and Development Program of China in $13^{\text {th }}$ Five-year Plan (2016YFC0502601) 
and the National Natural Science Foundation of China (41671041).

\section{Conflict of Interest}

The authors declare no conflict of interest.

\section{References}

1. BESNARD E., CHENU C., ROBERT M. Influence of organic amendments on copper distribution among particle-size and density fractions in champagne vineyard soils. Environental Pollution 112 (3), 329, 2001.

2. SINGH U.K., KUMAR B. Pathways of heavy metals contamination and associated human health risk in Ajay River basin, India. Chemosphere 174, 183, 2017.

3. LI H.X., JI H.B., SHI C.J., GAO Y., ZHANG Y., XU X.Y., DING H.J., TANG L., XING Y.X. Distribution of heavy metals and metalloids in bulk and particle size fractions of soils from coalmine brownfield and implications on human health. Chemosphere 172, 505, 2017.

4. LI L.J., SHEN X.Y. Development progress and breeding status of the Wumeng semi-fine wool sheep. Guizhou Agriculture Science 38 (11), 182, 2010.

5. SONG C.J., SHEN X.Y. Effects of environmental zinc deficiency on antioxidant system function in Wumeng semi-fine wool sheep. Biological Trace Element Research 195 (1), 110, 2019.

6. HUO B., WU T., SONG C.J., SHEN X.Y. Effects of selenium deficiency in the environment on antioxidant systems of Wumeng semi-fine wool sheep. Polish Journal of Environmental Studies 29 (2), 1649, 2020.

7. CHI Y.K., XIONG K.N., CHRN H., MIN X.Y., XIAO H., LIAO J.J., SHEN X.Y. Effect of grazing to copper pollution meadow on copper metabolism in Wumeng semi-fine wool sheep. Polish Journal of Environmental Studies 28 (3), 1083, 2019.

8. SHEN X.Y., CHI Y.K., XIONG K.N. The effect of heavy metal contamination on humans and animals in the vicinity of a zinc smelting facility. Plos One 14 (10), e0207423,2019.

9. YUAN R. Effect of fertilizer treatment to copper pollution meadow on copper metabolism in Guizhou semi- fine wool sheep. Lanzhou: Lanzhou University, 2012.

10. HUO B., WU T., CHI Y.K., MING X.Y., SHEN X.Y. Effects of molybdenum fertilizer application on copper metabolism of Wumeng semi-fine wool sheep in copper polluted grassland. Acta Ecologiae Animalis Domastici 40 (7), 44, 2019.

11. SHEN X.Y. Effect of nitrogenous fertilizer treatment on mineral metabolism in grazing yaks. Agricultural Sciences in China 8 (3), 101, 2009.

12. ZHAO K., HUO B., SHEN X.Y. Studies on antioxidant capacity in selenium-deprived the Choko yak in the Shouqu prairie. Biological Trace Element Research 2020. DOI:10.1007/s12011-020-02461-9

13. GB 15618-2018, Soil environmental quality risk control standard of soil contamination of agricultural land (Trial).Beijing, Ministry of Ecology and Environment of the People's Republic of China.

14. SHEN X.Y., HUO B., GAN S.Q. Effects of nano-selenium on antioxidant capacity in se-deprived tibetan gazelle (procapra picticaudata) in the Qinghai-Tibet plateau. Biological Trace Element Research 2020. DOI:10.1007/ s12011-020- 02206-8

15. SHEN X.Y., HUO B., WU T., SONG C.J., CHI Y.K. iTRAQ-based proteomic analysis to identify molecular mechanisms of the selenium deficiency response in the przewalski's gazelle. Journal of Proteomics 203, 103389, 2019.

16. KHAN Z.I., AHMAD K., ASHRAF I., KHAN A., FARDOUS A., SHER M., AKRAM N.A., ASHRAF M., HAYAT Z., LAUDADIO V., TUFARELLI V., HUSSAIN A., ARSHAD F., CAZZATO E. Appraisal of trace metal elements insoil,forage and animal continuum: a case study on pasture irrigated with sewage water. Philippine Agricultural Scientist 99 (1), 80, 2016.

17. RUSSEL J.R., BISINGER J.J. Forages and pastures symposium: improving soil health and productivity on grasslands using managed grazing of livestock. Journal of Animal Science 93 (6), 2626, 2015.

18. SHEN X.Y., JIANG H.M., YUAN R., JIA Z.H. Effects of grassland fertilization on forage and grazing of Guizhou semi-fine wool sheep. Acta Prataculturae Sinica 21 (3), 275, 2012.

19. LIAO J.J., SHEN X.Y., HUO B., XIONG K.N. Effect of nitrogenous fertilizer on the antioxidant systems of grassland species in the karst mountains. Acta Prataculturae Sinina 27 (1), 169, 2018.

20. ZHAO K., CHI Y.K., SHEN X.Y. Studies on edema pathema in Hequ Horse in the Qinghai-Tibet Plateau. Biological Trace Element Research 198 (1), 142, 2020.

21. SHEN X.Y., JIANG Z.G. Changes of trace elements in forage grass of the first meander of the Yellow River. Chinese Journal of Grassland 30 (4), 118, 2008.

22. SHEN X.Y., MIN X.Y., ZHANG S.H., SONG C.J., XIONG K.N. Effect of heavy metal contamination in environment on antioxidant function in Wumeng semi-fine wool sheep in the southwest China. Biological Trace Element Research 198 (2), 505, 2020

23. SONG C.J., GAN S.Q., SHEN X.Y. Effects of nano-copper poisoning on immune and antioxidant function in the Wumeng semi-fine wool sheep. Biological Trace Element Research 198 (2), 515, 2020.

24. LIU S.L., HUA D.L., ZHANG B.Y., JIE X.L., LIU F., HU H.F., MA C. Effects of zinc, iron and molybdenum combined application on yield and quality of alfalfa. Chinese Journal of Grassland 16 (2), 176, 2008.

25. SHEN X.Y., JIANG Z.G. Serum biochemical values and mineral contents of tissues in przewalski's and Tibetan gazelles. African Journal of Biotechnology 11 (3), 718, 2012.

26. SHEN X.Y., SONG C.J. Responses of Chinese merino sheep (junken type) on copper-deprived natural pasture. Biological Trace Element Research 2020. DOI:10.1007/ s12011-020-02214-8

27. SONG C.J., GAN S.Q., HE J., SHEN X.Y. Effects of nanozinc on immune function in Qianbei-pockmarked goats. Biological Trace Element Research 2020. DOI:10.1007/s 12011-020-02182-z

28. WU T., SONG M.L., SHEN X.Y. Seasonal dynamics of copper deficiency in Wumeng semi-fine wool sheep. Biological Trace Element Research 197 (2), 487, 2020.

29. SHEN X.Y., SONG C.J., WU T. Effects of nano-copper on antioxidant function in copper-deprived Guizhou black goats. Biological Trace Element Research 2020. DOI:10.1007/s12011-020-02342-1 
30. LI Y.F., HE J., SHEN X.Y. Effects of nano-selenium poisoning on immune function in the Wumeng semi-fine wool sheep. Biological Trace Element Research 2020. DOI:10.1007/s12011-020-02408-0

31. HUO B., WU T., SONG C.J., SHEN X.Y. Studies of selenium deficiency in the Wumeng semi-fine wool sheep. Biological Trace Element Research 194 (1), 152, 2019.

32. WANG Y.C., JIANG L., LI Y.F., LUO X.Y., HE J. Effect of different selenium supplementation levels on oxidative stress, cytokines, and immunotoxicity in chicken thymus. Biological Trace Element Research 172 (2), 488, 2016.

33. ROMAN M., JITARU P., BATBANTE C. Selenium biochemistry and its role for human health. Metallomics 6 (1), 25, 2014.

34. HERENA Y.H., NAGHUM A., MARLA J.B., LUCIA A.S. From selenium absorption to selenoprotein degradation. Biological Trace Element Research 192 (1), 26, 2019.

35. NAZ H., ABDULLAH S., ABBAS K., HASSAN W, BATOOL M, PERVEEN S., MAALIK S., MUSHTAQ S. Toxic effect of insecticides mixtures on antioxidant enzymes in different organs of fish, Labeo rohita. Pakistan Journal of Zoology 51 (4), 1355, 2019.

36. IQRA B., MOOLCHAND M., PERSHOTAM K., SAEED A.S., HIRA S. Effect of dietary selenium yeast supplementation on morphology and antioxidant status in tests of young goat. Pakistan Journal of Zoology 51, 979, 2019.

37. KANANFCHIAN M., ESMAEILZADEH S., MAHJOUB S. Status of serum copper, magnesium, and total antioxidant capacity in patients with polycystic ovary yndrome. Biological Trace Element Research 193, 111, 2020.

38. CHEN M., MAHFUZ S., CUI Y., JIA L.Y., LIU Z.J., SONG $\mathrm{H}$. The antioxidant status of serum and egg yolk in layer fed with mushroom stembase (flammulina velutipes). Pakistan Journal of Zoology 52 (1), 389, 2019.

39. XIE Z.Z., LIU Y., BIAN J.S. Hydrogen sulfde and cellular redox homeostasis. Oxidative Medicine and Cellular Longevity 2016, 1, 2016.

40. ZENG T., LI J.J., WANG D.Q., Li G.Q., Wang G.L., Lu L.Z. Effects of heat stress on antioxidant defense system, inflammatory injury, and heat shock proteins of Muscovy and Pekin ducks: evidence for differential thermal sensitivities. Cell Stress \& Chaperones 19 (6), 895, 2014.

41. GEORGIEVA N.V., STOYANCHEV K., BOZAKOVA N. Combined effects of muscular dystrophy, ecological stress, and selenium on blood antioxidant status in broiler chickens. Biological Trace Element Research 142 (3), 532, 2011. 